\title{
THE OVERVIEW-ANALYTICAL DOCUMENT OF THE INTERNATIONAL EXPERIENCE OF BUILDING SMART CITY
}

\author{
Iryna BASHYNSKA ${ }^{1}$, Anastasia DYSKINA ${ }^{2}$ \\ Odesa National Polytechnic University, Odesa, Ukraine \\ E-mails: ${ }^{1}$ i.bash@ukr.net (corresponding author); ${ }^{2}$ diskina84@gmail.com \\ Received 07 June 2018; accepted 12 October 2018
}

\begin{abstract}
The population of the planet is constantly growing, people are moving to the cities. Recently, more and more interest is being given to smart cities as a guarantee of at least comfortable living of citizens, as a maximum - an ultramodern autonomous city with artificial intellect, anticipating the needs of residents, capable of functioning autonomously for a long time. The purpose of the article is to analyze the experience of smart cities, highlight the distinctive and common features and outline the initial stages of the route map for the development of a specific city into a smart city. After the study, it became clear that the concept of "smart city" is very broad, scientists are investing a huge number of parameters that characterize a smart city, but it was possible to identify common characteristics. Also, the hypothesis was tested that the city's urbanization should be oriented towards the inhabitants of this city, i.e. implemented not by a single algorithm, but by an algorithm that is adapted to the needs of a particular city. We proposed a methodology for the preparatory stage of the city's self-mastering, which is based on expert assessments by a prior ranking, includes 2 stages and which was tested on the example of Odessa (Ukraine). At the first stage, the questionnaire contained questions about the six main characteristics of a smart city. At this stage three characteristics were singled out, which are of particular concern to Odessa citizens and the second survey contained 36 clarifying questions only for these three characteristics. The results allowed to distinguish 6 characteristics from which it is necessary to start Odessa's growth as a smart city.
\end{abstract}

Keywords: smart city, smart city concept, Kyiv Smart City 2020, Songdo, Masdar, Odessa, coefficient of concordance.

JEL Classification: I31, O18, O39.

\section{Introduction}

The concept of "smart cities" is gaining popularity over the last 10 years. That is why, at the beginning of the previous decade, the global IT-leaders have come to the smart cities market and offer city governments comprehensive urban management solutions. In practice realize and scale to different cities this integrated approach was not fully implemented. So far smart city is a set of isolated vertical solutions. To integrate them on the basis of single digital platforms is an urgent and difficult task for business and city authorities.

Today, smart city does not replace the development of society with technological rearmament of the urban environment. People's participation in the processes of management, improvement, joint use of property becomes the subject of attention not only urbanites and sociologists, but also representatives of business. The most advanced of them are convinced that the main consumer in the market of smart cities will be a citizen, surrounded by real-time information services, is ready to pay for living in clean and safe neighborhoods, in energy-efficient buildings using affordable and fast transportation. Consequently, the creation of the concept of smart city is one of the most urgent and debatable issues for the development of the infrastructure of the entire city.

Preliminary research has shown that at the moment there is a fairly large number of cities that can be considered a smart city. At the same time, they have many common characteristics, but there are also unique, respectively, it was previously revealed that there is no standard for measuring

Copyright @ 2018 The Authors. Published by VGTU Press.

This is an Open Access article distributed under the terms of the Creative Commons Attribution License (http://creativecommons.org/licenses/by/4.0/), which permits unrestricted use, distribution, and reproduction in any medium, provided the original author and source are credited.. 
urbanization. Thus, the main purpose of the study is to develop recommendations for starting the construction of a smart map for any city. The preliminary hypothesis consists of the following: the map of a city's smartization is unique, but is based on unified defined criteria, which need to be identified by studying international experience.

After this introduction, we present a literature review. Later, we conduct the theoretical and empirical analysis. Then, we discuss the results. Finally, we present the conclusions.

\section{Literature review}

Recently, many scientists discuss the concept of smart city, both in general and locally, delving into specific aspects.

The paper "Smart Cities" by Betis et al. (2018) as well as Edy Portmann et al. (2016), brought together recent international research on one of the most challenging and multidisciplinary subjects of present and future engineering, architectural, medical, economic, information, and social sciences: the smart city paradigm. The article aims to analyze the features of "smart cities" and show how composed current international technological trends in basic urban infrastructure segments to be used in the future. Petar Solic et al. (2018) analyzed a set of papers that deal with a number issues appearing in the process of moving towards building efficient smart cities architectures. Gathered technical contributions went throughout standard review process with at least three reviews per paper. Total of 12 accepted contributions are divided into three main groups; ranging from the hardware to the upper networking layers and finally ending with application layer. Harish Kumar et al. (2018) explore all the possible services among various city dimensions which can make a city smart. The ideas related to smart services are collected from the peer vetted creative crowdsourcing process performed online in India.

Many scientists have studied their cities (Achmad et al. 2018, Woyke 2018, Bradbeer and Tsang 2018) and countries (Pinheiro Junior and Cavalheiro 2017, Dias and Cacho 2018, Gómez-Expósito et al. 2018) on the subject of whether or not they are smart, which part corresponds to the conventional indicators of smart city, what factors hinder the further development in this direction and which steps should be taken.

In view of the fact that it is not always possible to evaluate all aspects of a smart city, some authors are deepening into one of the factors: explain the sustainable technologies that will make tomorrow's smart cities pleasant places to live (Hammoudeh and Arioua 2018, Bardell 2018); Smart city readiness (Achmad et al. 2018); the developing a more realistic and ultimately more practical smart city (Finger and Razaghi 2016, Shahidehpour et al. 2018); ecosystems of smart city (Attour and Burger-Helmchen 2015); crowdsourced smart cities (Alizadeh 2018); Energy Saving (Pan and Cheng 2018, Lu et al. 2018, Hou et al. 2018), Green technologies for Smart Cities (Zhou et al. 2018, Zhang et al. 2018, Kai et al. 2018), Smart Governance (Gascó et al. 2016, Razaghi and Finger 2018, Almeida et al. 2018, Zambonelli et al. 2018); sustainable urban transformation (Ernst et al. 2015); Smart Mobility (Nicolaï and Le Boennec 2018, Geoffron 2017); Smart Society (Cifaldi and Serban 2018), Smart Healthcare (Cook et al. 2018, Venkatesh et al. 2018, Chaudhary et al. 2018, Wang et al. 2018) and so on.

The term "smart city" can be interpreted broadly and differently. But in any way, information and telecommunication technologies that help solve public problems within the framework of a multilateral partnership between citizens, business and government (European Parliament 2014, Dyskina 2017) play a key role. This understanding dates back to 1993 in the Silicon Valley, USA, where the concept of "smart community" appeared. Such communities were defined as any purposeful co-operation between businesses and residents in terms of improving living and working conditions with the use of accessible information technologies (Lindskog 1997).

\section{Methodology}

Scientific research is considered in continuous development and is based on the connection between theory and practice (step-by-step methodology, as well as the relationship between theory and practice, is shown in Figure 1). At the first stage of the scientific work the research is conducted in the theoretical direction. The authors solved the tasks of this stage with the help of observation, measurement and description.

Theoretical tasks were aimed at studying and identifying the causes, relationships, and dependencies that make it possible to establish the behavior of an object-the process of building a smart city, to identify and study its characteristic features and features on the basis of the principles and methods of cognition developed in science. Here the use of axiomatic methods, systemic, structural-functional analysis predominated. As a result of the knowledge, the authors formulated a hypothesis: it is possible to single out the main characteristics of a smart city, but in order to build a city map, it is necessary to coordinate the initial directions with the inhabitants of this city.

Theoretical cognitive tasks were formed in such a way that they could be tested empirically, which is carried out at the second stage of the study. At this stage, statistical methods (questioning, poll), method of expert evaluations, mathematical modeling and for speeding up the process of automated data processing prevailed.

In particular, to test the hypothesis, a method of a priori ranking of expert estimates was used. For this in two stages 


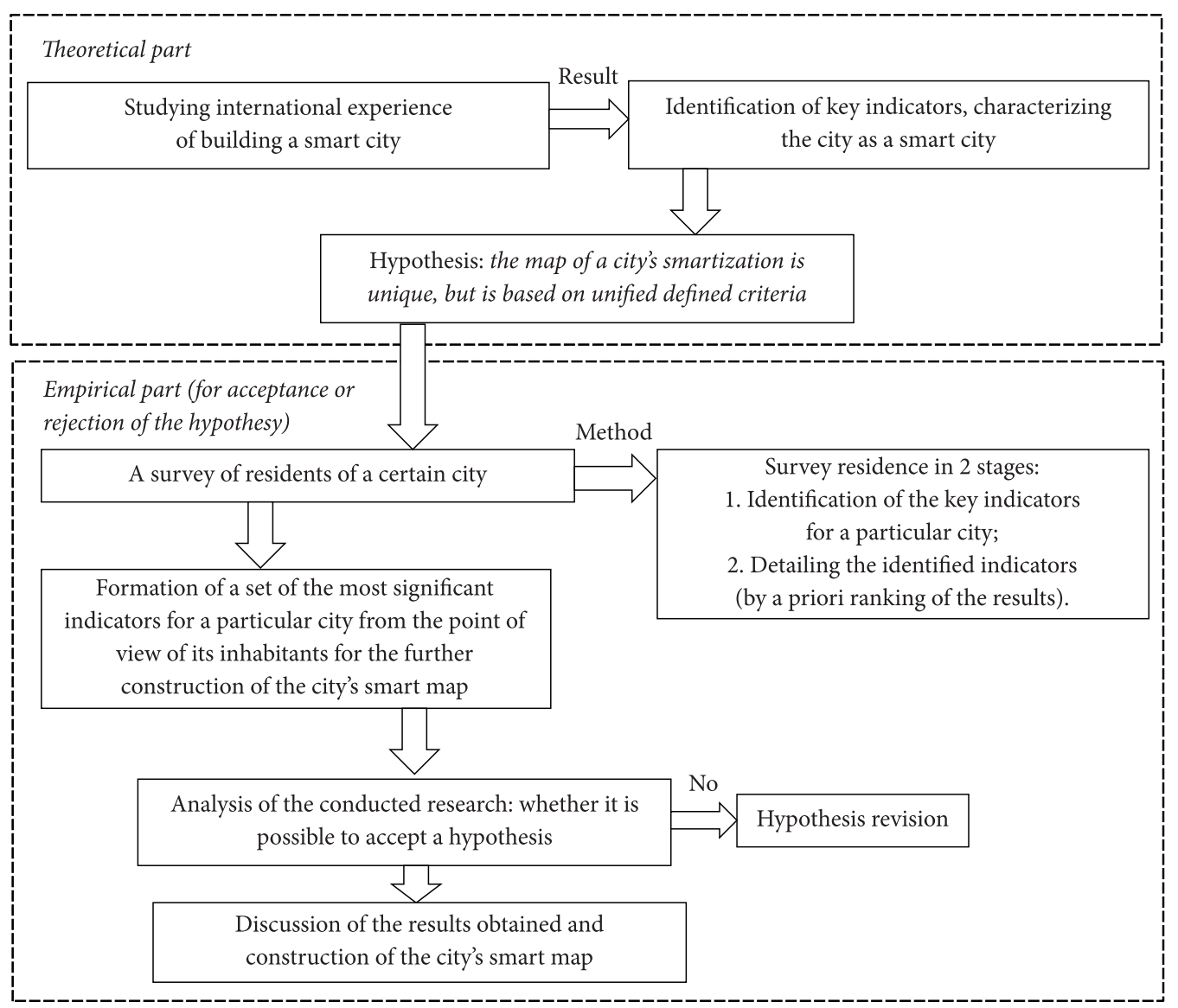

Figure 1. The schema of the methodology (source: authors 2018)

Table 1 . The results of the conducted survey of residents of Odessa online and internally (source: authors 2018)

\begin{tabular}{|c|c|}
\hline \multicolumn{1}{|c|}{ Sample size } & Ppl. (\%) \\
\hline 1 stage & 396 \\
\hline Online & $312(78.7 \%)$ \\
\hline In a personal meeting & $84(21.3 \%)$ \\
\hline 2 stage & 594 \\
\hline Online & $398(67.0 \%)$ \\
\hline In a personal meeting & $196(33.0 \%)$ \\
\hline Age (total for 2 stages) & \\
\hline $10-18$ & $8.4 \%$ \\
\hline $18-28$ & $14.6 \%$ \\
\hline $28-45$ & $57.6 \%$ \\
\hline $45-75$ & $16.2 \%$ \\
\hline No data & $3.2 \%$ \\
\hline Education (total for 2 stages) & \\
\hline Without education & $10.1 \%$ \\
\hline Specialized secondary & $9.4 \%$ \\
\hline Incomplete higher education & $21.4 \%$ \\
\hline Higher education & $42.0 \%$ \\
\hline PhD & $12.8 \%{ }^{*}$ \\
\hline No data & $4.3 \%$ \\
\hline
\end{tabular}

Note: ${ }^{*}$ The professional sphere of authors has slightly distorted the sample around the city, because Surveys were conducted among colleagues also. we conducted a survey of residents of Odessa online and internally. Table 1 presents the gender, age, and educational attainment for the sample.

At the first stage, the questionnaire contained questions about the six main characteristics of a smart city. We checked the results of the survey for consistency of opinions, using the concordance coefficient and the questionnaires were processed by the a priori ranking method using MS Excel (more details are considered below). At this stage, three characteristics were singled out which are of most concern to Odessa citizens and the second survey contained 36 clarifying questions (both open and closed) only for these three characteristics, such as:

- Do you consider the work of the City Hall transparent?

- How do you assess the work of transport?

- You are satisfied with the quality (transport services, housing, health care, educational services, public and social services, etc., your option);

- You are satisfied with the state (cultural facilities, health facilities, education facilities, etc., your option);

- Which of the following should be improved in the first place (the condition of the beaches, road conditions, etc., your option); 
- Which of the following should be allocated additional funding (public transport renewal, housing repair, repair of tourist facilities, video surveillance, etc., your option);

- Estimate from 0 to 10 the degree of coverage of the city's transport network, where 0 - public transport goes only along the main streets and avenues of the city, 10 - by public transport you can get absolutely to all the streets of the city and so on.

We chose certain questions so that you can see that they were clear, varied, some overlapping. A large part of the questions also implied the statement of personal opinion, so as not to miss important details. To bring the entire list of questions is not necessary, because he is second-rate.

The processing of the results was carried out in a similar manner to the first stage and allowed to distinguish 6 characteristics from which it is necessary to start the Odessa's dismantling.

\subsection{Theoretical direction}

\subsubsection{The international experience of building smart city}

In Ukraine, the term "smart city" is also gaining momentum. In November 2013 the seventh time in Kiev hosted the International Forum of smart-city and exhibition under the same name. The forum considered new approaches to urban development, security, ecology, housing and transport infrastructure, and social sphere. The exhibition presented the latest technologies of intellectual construction, leading world technologies, equipment and solutions in the context of the entire city. The concept of Kyiv Smart City 2020 (2017) development provides the following key areas:

- improving the quality of life of citizens;

- modernization of physical and technological infrastructure development of the city;

- use of technologies for effective city management;

- compliance with environmental standards, sustainable economic development and social inclusion;

- active public involvement.

The concept of Kyiv Smart City was created on the basis of the British Institute of Standards methodology. The document suggests the city's vision of smart city, which includes important conceptual foundations of smart city that distinguish cities from cities that are engaged in the introduction of electronic services or automation processes.

Thus, the first step towards building the concept of Kyiv Smart city is that Kyiv must become an innovative city, that is, it will be aimed at creating an innovative ecosystem of the city, which combines territorial communities aimed at collective actions in the field of creating knowledge flows, support for technological development and commercialization of innovations.

In practice, this is a combination of inventors, incubators, venture business and intellectual property institutions, and in the case of smart grandeur, creating a smart city hub, research laboratories, open source data incubators, educational centers, smart city schools and innovation education (as in form both in terms of content), computer centers from the smart grid and others.

The innovation ecosystem should include three components, namely education (research, progressive scientists), activation of innovations (implementation) and their output on a broad market, that is, business. It is a prerequisite for the transformation of the city in a smart city. Thus, innovative ecosystem allows the city to become more competitive and comfortable for residents. There are some smart conditions in Kyiv, namely the presence of a significant number of educational centers, an environment for innovation (coworkings and first incubators), 90,000 registered IT outsourcing companies, but this still needs further development.

The second direction is extremely important, which emphasizes the majority of sociological surveys - this is a matter of transforming city management. The fact that the concept of Smart city - is not only the introduction of e-services, but also qualitative change in management (Mutiara et al. 2018). The strategic approach to Smart city concept is when the problems are solved by increasing the managerial and technological level, which means finding solutions, new design and reengineering processes along with technological solutions, namely:

1. Urban data - the organization of data collection should become the center for turning the city into a smart city and the basis for the introduction and development of new management processes, models and functions. All smart grids are closely linked to ICT, but these devices are worthless without a wellestablished data management;

2. Development of integrated and open IT infrastructure of the city;

3. Integration of management systems and the creation of integrated services and solutions (not just the automation of existing ones) - that is, the introduction of the principle of managerial interoperability beyond the technical;

4. Development of partnership and cooperation between the city government, businesses and citizens to develop modern services, improving them based on clear KPIs.

The third step towards building a Kyiv smart city concept - without which no "smart city" in the world can do - is involving citizens in managing the city. According to sociology in the capital, there is a very high demand for public participation and it is no coincidence that the e-petition and e-budgeting service that is already operating in Kyiv is developing so actively. Smart City is a city of smart citizens. That is why it is not only a matter of developing democracybased e-formats. But as proposed in the concept, creating 
a wide range of opportunities for citizens to participate in city management. For example, the creation of special working groups on e-government, anti-corruption council and public information. In modern cities around the world, any tools are used to engage citizens in strategic processes and decision-making, assessing the quality of services and the work of officials.

The fourth component of the Kyiv Smart city concept is transforming the city into a comfortable and modern one, but it is about quality of life here and the city's compliance with the international standards proposed for the implementation of ISO 37120. To do this, key priorities were identified, as a result of a survey of key groups of influence in the city were identified: representatives of the departments of the Kyiv city state administration, business, the public and the IT community. The polls confirm that Ukraine is far behind the modern European and successful cities of the world.

A very important aspect for introducing the concept of Kyiv Smart city is the need to appeal to international experience and expert organizations, as well as search for resources for investing in Kyiv Smart city concept in international markets, EU funds and special programs. In fact, it is necessary to create an external innovation ecosystem around Kiev, the city must go to the international Smart city environment, which is very actively developing, growing and becoming competitive.

In today's discussions at the international level, the concept of a smart city is not confined only to technologies as the main factor of development. Truly smart are cities that create conditions for the growth of human capital. The more these opportunities and the more favorable the environment, the smarter the city. This approach was the basis of the European vision of a smart city and was described in 2007 by the Center for Regional Science of the Vienna University of Technology, which is presented in Table 2.
A smart city is strategically suited to the development of these six areas, while wisely utilizing the resources and activity of its residents, acting consciously and independently. The authors of the definition emphasize that the main thing - to maintain the integrated principle of development and the list of components given - is not exhaustive.

The definition of the European Parliament (2014) is based on the same six points. According to him, a smart city seeks to solve social problems, using IT solutions in the activities of various municipal entities and their partnerships (Ministry of Infrastructure of Ukraine 2014). At the same time, the European Parliament points to the problematic context: smart cities are seen as responses to the challenges of large-scale urbanization (overpopulation, energy consumption, resource allocation, environmental protection). Cities are turning into strategic points for addressing poverty and inequality, unemployment and energy flows management.

By definition of community and forum "Global smart cities" (World Smart city 2016), created by the International Organization for Standardization (ISO), International Electrotechnical Commission (IEC) and the International Telecommunication Union (ITU), smart city is sustainable and resilient. Sustainability implies that current needs can be met without undermining the opportunities of future generations - in the environmental, social and economic aspects. Resilient means that the city is successfully adapting to changing conditions that exist.

Smart city in its best, according to international organizations is:

- male-centric (focused on people, businesses, workers, tourists, etc.);

- well managed;

- accessible and open (for all people and new ideas);

- discloses data about its activities;

- protects personal data;

Table 2. Characteristics of a smart city (source: author 2018)

\begin{tabular}{|c|c|c|c|c|c|}
\hline $\begin{array}{l}\text { 1. Smart environment } \\
\text { (natural resources) }\end{array}$ & $\begin{array}{l}\text { 2. Smart living } \\
\text { (quality of life) }\end{array}$ & $\begin{array}{l}\text { 3. Smart people } \\
\text { (social and human } \\
\text { capital) }\end{array}$ & $\begin{array}{l}\text { 4. Smart economy } \\
\text { (competitiveness) }\end{array}$ & $\begin{array}{c}\text { 5. Smart mobility } \\
\text { (transport and ICT) }\end{array}$ & $\begin{array}{l}\text { 6. Smart governance } \\
\text { (participation) }\end{array}$ \\
\hline $\begin{array}{l}\text { 1.1. Attractivity of } \\
\text { natural conditions } \\
\text { 1.2. Pollution } \\
\text { 1.3. Environmental } \\
\text { protection } \\
\text { 1.4. Sustainable } \\
\text { resource } \\
\text { management }\end{array}$ & $\begin{array}{l}\text { 2.1. Cultural } \\
\text { facilities } \\
2.2 \text {. Health } \\
\text { conditions } \\
2.3 \text {. Individual } \\
\text { safety } \\
\text { 2.4. Housing } \\
\text { quality } \\
\text { 2.5. Education } \\
\text { facilities } \\
\text { 2.6. Touristic } \\
\text { attractivity } \\
2.7 . \text { Social } \\
\text { cohesion }\end{array}$ & $\begin{array}{l}\text { 3.1. Level of } \\
\text { qualification } \\
\text { 3.2. Affinity to life } \\
\text { long learning } \\
\text { 3.3. Social and } \\
\text { ethnic plurality } \\
\text { 3.4. Flexibility } \\
\text { 3.5. Creativity } \\
\text { 3.6. Cosmopo- } \\
\text { litanism/ Open- } \\
\text { mindedness } \\
\text { 3.7. Participation in } \\
\text { public life }\end{array}$ & $\begin{array}{l}\text { 4.1. Innovative } \\
\text { spirit } \\
\text { 4.2. Entrepre- } \\
\text { neurship } \\
\text { 4.3. Economic } \\
\text { image \& trade- } \\
\text { marks } \\
\text { 4.4. Productivity } \\
\text { 4.5. Flexibility of } \\
\text { labour market } \\
\text { 4.6. International } \\
\text { embeddedness } \\
\text { 4.7. Ability to } \\
\text { transform }\end{array}$ & $\begin{array}{l}\text { 5.1. Local } \\
\text { accessibility } \\
\text { 5.2. (Inter-) national } \\
\text { accessibility } \\
\text { 5.3. Availability of } \\
\text { ICT-infrastructure } \\
\text { 5.4. Sustainable, } \\
\text { innovative and safe } \\
\text { transport systems }\end{array}$ & $\begin{array}{l}\text { 6.1. Participation in } \\
\text { decision-making } \\
\text { 6.2. Public and } \\
\text { social services } \\
\text { 6.3. Transparent } \\
\text { governance } \\
\text { 6.4. Political strate- } \\
\text { gies \& perspectives }\end{array}$ \\
\hline
\end{tabular}


- based on integrated services and infrastructure;

- proactive in the education and development of citizens.

The technological aspect of Smart city is reflected in the definition of IBM (2010) and the company has become one of the leading promoters of the concept of Smart city. The leader of the global IT-market considers smart city as "instrumented, interconnected and intellectual". "Instrumented" means the ability to get different data on urban life and infrastructure in real time with sensors, measuring devices, personal devices. "Interconnected" points to the ability to integrate data on digital platforms, providing universal access to various city services. "Intelligent" refers to the processing of the information obtained through the services of advanced analytics, modeling, optimization and visualization in order to make the best decisions.

Only in Europe there are more than 240 cities claiming the status of smart according to Top 5 smartest Smart Cities in the world (2017). It is difficult to estimate their exact number, since the only criteria for assigning cities to the category Smart is not developed. Existing ratings present both socio-economic indicators of the effectiveness of innovations, as well as the degree of availability of technological infrastructure.

The implementation of "Smart City" projects has prompted research institutions to develop Smart city measurement indexes, the most popular of which are presented in Table 3.

Analyzing the data presented, we can draw the following conclusion that it is often impossible to find the necessary indicators at the city level (most of them available at the regional level), therefore, researchers have to use average values; with most indices it is impossible to work dynamically, to compare indicators for different years, due to changes in methodology and the number of countries participating in the study; most research is based on the processing of large cities (usually capitals), avoiding the middle and small cities.

\subsubsection{Stages of development of the concept of smart city}

World practice allows distinguishing three conditional phases of formation of smart cities, reflecting the change of key technologies and types of projects under implementation (Table 4).

To date, there are already concepts about the reference architecture of a smart city, and within the framework of individual projects worked out critical technologies. There is a need to exit isolated vertical projects to common platforms that provide access to data and provide all the security requirements. This approach, according to the European ideologues Smart city, will provide a transition from "digital" bridge to a truly intelligent.

Smart cities of the first phase of the development of the concept of smart city include those that were reduced from scratch by big players in the IT industry. The purpose of the management companies was to test the solutions developed. According to plans, the new city was completely built up with smart buildings, intelligent energy and transport networks were built. Examples of Smart city 1.0 - Masdar (UAE) and Songdo (South Korea).

The full name of Songdo is Songdo International Business District. The project was conceived in the mid1990s by the industrial giant Daewoo, and was later redeemed by the American developer Gale International and the South Korean company POSCO E \& C. The project has been officially launched since 2001, with about \$ 35 billion invested; now it is completed at $70 \%$ (Shapiro 2015). Network equipment for the city has been developed by Cisco. A central control node is created, which, based on the received data (RFID tags, sensors), regulates traffic flows and energy flows.

Transport model of the city so that residents could abandon the car, any place can be reached in 15 minutes, $25 \mathrm{~km}$ paved bicycle paths, buses and subways. At the same time, numerous charging stations for hybrid and electric vehicles

Table 3. Indices of measurement of "smart cities" (source: Arcadis and the Center... 2016, Cities Economy General Urban Governance IESE... 2017, Ericsson 2017, City Prosperity Initiative 2017)

\begin{tabular}{|l|l|c|c|l|}
\hline \multicolumn{1}{|c|}{$\begin{array}{c}\text { Indices of } \\
\text { measurement }\end{array}$} & \multicolumn{1}{c|}{$\begin{array}{c}\text { Responsible } \\
\text { organization }\end{array}$} & $\begin{array}{c}\text { Year / } \\
\text { Frequency }\end{array}$ & $\begin{array}{c}\text { Number of } \\
\text { cities }\end{array}$ & \multicolumn{1}{|c|}{ Measurement Criteria } \\
\hline $\begin{array}{l}\text { Arcadis sustaina- } \\
\text { ble city index }\end{array}$ & $\begin{array}{l}\text { Arcadis and Center } \\
\text { for Academic and } \\
\text { Business Research } \\
\text { (Cebr) }\end{array}$ & 2015 / annually & 100 & $\begin{array}{l}3 \text { categories: social (people), ecological (planet) and eco- } \\
\text { nomic (profit). }\end{array}$ \\
\hline $\begin{array}{l}\text { Cities in motion } \\
\text { index }\end{array}$ & $\begin{array}{l}\text { Spanish Business } \\
\text { School IESE }\end{array}$ & $2013 /$ annually & 180 & $\begin{array}{l}10 \text { key areas: economics, human capital, technology, envi- } \\
\text { ronment, international advocacy, social cohesion, mobility } \\
\text { and transport, governance, urban planning and public } \\
\text { administration. }\end{array}$ \\
\hline $\begin{array}{l}\text { Networked society } \\
\text { city index }\end{array}$ & Ericsson & $2011 /$ annually & 41 & $\begin{array}{l}4 \text { characteristics: sustainability, cooperation, participation } \\
\text { and mobility. }\end{array}$ \\
\hline $\begin{array}{l}\text { City prosperity } \\
\text { index }\end{array}$ & UN-Habitat & 60 & $\begin{array}{l}6 \text { categories: productivity, infrastructure development, } \\
\text { quality of life, social engagement, environmental sustaina- } \\
\text { bility, governance and legislation. }\end{array}$ \\
\hline
\end{tabular}


Table 4. Stages of development of the concept of smart city (source: authors 2018)

\begin{tabular}{|l|l|l|l|}
\hline \multicolumn{1}{|c|}{ Criteria } & \multicolumn{1}{|c|}{ Smart city 1.0 } & \multicolumn{1}{|c|}{ Smart city 2.0 } & \multicolumn{1}{c|}{ Smart city 3.0 } \\
\hline $\begin{array}{l}\text { Networks and } \\
\text { communication }\end{array}$ & $\begin{array}{l}\text { GIS-Informing. } \\
\text { Leading terrestrial } \\
\text { communication } \\
\text { channels }\end{array}$ & $\begin{array}{l}\text { Smart Networks, Wireless } \\
\text { Internet Access Points, 3G / 4G, } \\
\text { Wireless Broadband Services }\end{array}$ & $\begin{array}{l}\text { Semantic networks, aggregated data, open source data } \\
\text { for pattern recognition, generation of alerts, visuali- } \\
\text { zation of information, predictive analytics (semantic } \\
\text { web, predictive analytics) }\end{array}$ \\
\hline Transport & $\begin{array}{l}\text { Centralized moni- } \\
\text { toring and trans- } \\
\text { port management } \\
\text { systems }\end{array}$ & $\begin{array}{l}\text { Intelligent transport (hybrid } \\
\text { systems for transport) - automa- } \\
\text { ted traffic management systems } \\
\text { (intelligence transport, GIS map) }\end{array}$ & $\begin{array}{l}\text { Related transport (renewable energy for transport) - } \\
\text { unmanned control, autonomous service (Connected } \\
\text { transport, autonomous vehicle) }\end{array}$ \\
\hline $\begin{array}{l}\text { Data processing } \\
\text { and storage }\end{array}$ & $\begin{array}{l}\text { Vertical isolated } \\
\text { data acquisition } \\
\text { system based on } \\
\text { RFID-technology }\end{array}$ & $\begin{array}{l}\text { Internet of Things: integration } \\
\text { of sensor and identification } \\
\text { technologies and standards and } \\
\text { protocols between machine inte- } \\
\text { ractions. Computer Computing } \\
\text { and Analysis (Big Data) }\end{array}$ & $\begin{array}{l}\text { Ubiquitous computing of collected data (introduction } \\
\text { of microprocessor controllers in a variety of types of } \\
\text { household and industrial equipment). Cloud compu- } \\
\text { ting, sensor networks in combination with Web 2.0, } \\
\text { social networks, crowdsourcing platforms for collective } \\
\text { computing. }\end{array}$ \\
\hline $\begin{array}{l}\text { Electronic } \\
\text { services }\end{array}$ & $\begin{array}{l}\text { Electronic payment } \\
\text { of city services }\end{array}$ & $\begin{array}{l}\text { Urban service platforms (e-par- } \\
\text { king, e-ticketing, e-commerce) }\end{array}$ & $\begin{array}{l}\text { Standardization of urban services platforms based on } \\
\text { the Internet of things }\end{array}$ \\
\hline $\begin{array}{l}\text { Infrastructure } \\
\text { development }\end{array}$ & $\begin{array}{l}\text { Sustainable inf- } \\
\text { rastructure and } \\
\text { buildings }\end{array}$ & $\begin{array}{l}\text { Smart Networks, Wireless } \\
\text { Internet Access Points, 3G / 4G, } \\
\text { Wireless Broadband Services }\end{array}$ & BIM 1.0 (3D, visualization) \\
\hline Building design & CAD & Intelligent automated buildings and infrastructure \\
\hline
\end{tabular}

are installed in the city, and a free parking place for lowemission vehicles is organized.

Thanks to automation in Songdo, an efficient energy grid, adapted to changes in demand, has been formed. Energy consumption in each building has decreased by $30 \%$, since special glass allows to save on cooling of premises, install only LED lighting devices, use alternative sources of energy, and exhaust hot water heats up technical and residential premises.

An entire system of water saving solutions is developed. Rainwater is watered by street vegetation, washing streets. The sewage and water of the city canal are cleaned and also reused. Rooftop vegetation reduces storm drains; it absorbs sunlight and uses it for photosynthesis, cooling the surrounding air. As a result, clean water consumption in Songdo is approximately 10 times lower than in conventional cities. An entire system of water saving solutions is developed. Rainwater is watered by street vegetation, washing streets. The sewage and water of the city canal are cleaned and also reused. Rooftop vegetation reduces storm drains; it absorbs sunlight and uses it for photosynthesis, cooling the surrounding air. As a result, clean water consumption in Songdo is approximately 10 times lower than in conventional cities.

Gale International - a major shareholder and investor Songdo project - plans to extend such projects throughout Asia, and will be sold model of the city entirely.

In 2013, along with the city of Changsha, China began construction of the first appearance of Songdo city. Municipalities of Chinese cities Chongqing and Dalian have also agreed with Gale International on the creation of similar cities (Bondarev 2016).
Consequently, the technological successes of Songdo are so great that they affect many scientists. However, they do not quite meet the goals of the city to attract global companies and employees from around the world. It was with this calculation that the city was built from the city directly to the airport in Incheon, the largest transport hub in the country. But while in the business quarter there are 36,000 people, 90000 live in Great Songdo, and 99\% of people who have bought housing in the city are Koreans (Smart city of the future - Songdo (South Korea) - 2016). Young families come here because high schools are opened in the city. Songdo is not as comfortable for the life of the city. It is not so popular with the employees: the company employees do not like the "Stone Jungle" business district. The old model of infrastructure is also noted: there are no speed trains going between Songdo and Seoul towns, the city connects the usual route. However, office space is already occupied by $70 \%$. The management of Gale International believes that it will have to economically stimulate companies to move to Songdo city (Chronicle of events from... 2017).

The "Green" city of Masdar was designed in 2008 in accordance with the plan for the development of the nonraw materials industries of the United Arab Emirates. City, occupying 6 square. $\mathrm{km}$ near the capital and the international airport, there should not have been any emissions in the atmosphere at all. The project was estimated at 22 billion dollars, partly invested in it by the state-owned company Mubadala (The Arab world. Ecologically clean city of the future - Masdar in the UAE 2017). The project was developed by the British architectural firm Foster and Partners. According architects, in order to provide environmental cleanliness, city electric vehicles should be used. 
The buildings were designed to give a natural shadow; on the street mounted controllers that support a comfortable temperature regime and allow you to save on cooling. About 400 companies, including Siemens, Mitsubishi Heavy Industries, GE Ecomagination partners and others, placed in the business quarter, but mostly their presence there formally. There are about 2000 people working in the office buildings, and only 300 students of the Masdar Institute of Science and Technology always live in the city. The completion of the Maydar project shifted to 2030 (Goldenberg 2016). However, such plans for developers were hampered by the economic crisis and recession. Many potential investors have decided to postpone funding. As a result, by 2016, construction is completed only by $5 \%$. The route for autonomous vehicles had to consist of 100 stops, of which only two appeared. There is a station where you can rent bicycles - but to the nearest city, Abu Dhabi, 16 kilometers, and cycling paths are not built. In addition, managers announced that the original idea of total absence of emissions can not be realized. Unfortunately, today only $50 \%$ of emission reductions have been achieved compared to other UAE cities.

So, Smart City 1.0 is a municipality that maximizes the use of advanced technologies as a tool for viability, stability and control. These cities are often criticized for their technological orientation and the influential role of large corporations such as IBM and CISCO.

For the Smart city 2.0, a comprehensive strategic vision of the city's development is becoming an important part. For such projects, close cooperation between the city administration and a large technological company is required. The key trend - the introduction of integrated urban infrastructure management systems that would allow monitoring and dispatching of critical facilities, envisaged the emergence of threats. With such solutions, network managers move to a new level of management, and new types of services for citizens appear.

An example of the introduction of Smart city 2.0 is the cities of Busan (South Korea), Barcelona (Spain) and Brazil (Rio de Janeiro).

Busan City Hall, in partnership with Cisco, five local universities and the City Center for Mobile Application Development, has launched a security and monitoring system. The system operates on the basis of AGM's CityMind platform and allows you to analyze video images, detect patterns for analytics. According to Report Technologies for smart cities (2017) the complex of software solutions includes:

- Smart + Connected City Safety and Security - Street Surveillance;

- Smart + Connected City Traffic - Road Traffic Monitoring;

- Smart + Connected City Parking - intelligent parking space;
- Smart + Connected City Lighting - Smart City Lighting:

- Smart + Connected City Operations Centre Information Centre.

Also, in addition to mobile access, citizens can use the services of information booths, interactive displays. So, such a system provides working spaces, cloud platforms, test tools, smart devices, interfaces for access to municipal data and marketing resources, and advises startups and small companies.

Since 2012, the Municipal Institute of Informatics (IMI) of Barcelona has developed the Sentilo platform. It allows different sensor systems on urban infrastructure to exchange data. Sentilo is designed to further enhance the reach of devices and make functional add-ons.

Platform services are based on data from 9 thousand sensors that are located throughout the city and fix:

- air temperature;

- noise level;

- the level of loading of containers for garbage;

- level of loading of parking space;

- traffic;

- water level in reservoirs;

- electricity consumption;

- gas consumption;

- moistening the soil.

The project is being implemented with the participation of a wide range of industry partners. Most companies are suppliers of equipment and ready-made solutions that can be applied to project tasks. Several firms integrate their software with services available on the Sentilo platform.

The Rio de Janeiro municipality has launched a joint project with IBM to implement a monitoring system to prevent shifts in favelas located on the slopes of the hills. In the future, a full-fledged operation center was created on the basis of the information platform. It not only foresaw the weather, but also received data from all departments, allowing them to respond to emergency situations of any type, including crimes and accidents. IBM notes that in the project, the company was not only a developer and service provider, but a full-fledged advisor to the measure. Solutions tried out in Rio are supposed to be sold to other cities (Linsday 2010).

Thus, Smart city 2.0 is appropriate if the technology tools are specifically designed to address problems such as pollution, sanitation, health and transport, in agreement with their citizens. Unfortunately, the participation of citizens in the formal structure and decision-making meetings is imperfect and calls only a small minority.

So, the next generation of "smart cities" addresses the tasks of social inclusion, ensuring equal access to technologies, as well as budget savings and environmental protection. Citizens actively participate in local projects - share 
thoughts, complement the data of city services. For example, in the cities of the future inhabitants, having measured the air quality in playgrounds or in the whole area, agree joint efforts on additional landscaping and new pedestrian zones.

Answering the challenges of the previous stage of development, Smart City 3.0 claims the principle that a smart city can not exist without a reasonable village. Projects extend to the countryside: "Cities of the Future" in Japan tracks crop harvesting in surrounding areas, Smart Grids extend beyond the city to balance the flow of resources between the city and the countryside.

Another feature of "City 3.0" - maximum reuse of resources and common consumer products. The reference points of the "multi-turnaround economy" are points of exchange of bicycles, places where you can take repair tools and other examples of this kind.

A number of such initiatives in the field of smart government are implemented in London:

1. Community Talk London - an internet portal where discussions, polls, Q \& A sessions, focus groups are held (Zinchenko 2018). The themes range from simplifying the rental sector to the safety of cyclists. Policies consult with citizens to assess the effectiveness and relevance of the proposed activities in various urban communities. When registering on the portal, some information about the citizens is collected, which allows, for example, to invite certain groups of the population to join the discussion.

2. London Datastore opens over 500 datasets provides data on various aspects of urban life, and London Dashboard visualizes the statistics.

3. The Listen London platform collects user comments about political initiatives.

4. The Team London platform, funded by the Technology Strategy Board, organizes small volunteer projects and employment projects for young people.

5. London Schools Atlas interactively displays detailed information on all London schools, including attending classes, on the map, and also forecasts how many boys will qualify for school in the coming years.

Vienna regularly occupies top lines in the annual ranking of smart cities. Continuing to develop infrastructure projects, the city also launched a number of projects of another type. For example, in partnership with the local power company Wien Energy, the Vienna administration involves citizens as investors in solar power plants. This is consistent with the goals of renewable energy development that the city plans to achieve by 2050 (Mason 2015).

Citizens can pay a whole solar panel or half of it, and then Wien Energy "rent" the panel and annually pays 3.1\% of the purchase price to citizens. Since these panels come to a standstill in 25 years, the company remains in a win. The initiative was popular - all panels for two solar panels in the Leopoldau and Donaustadt districts were sold out for a week, and two more stations were later constructed in this way.

Thus, at the third stage, a reasonable city as a community of citizens not only follows the administration's instructions, but also independently organizes local projects. In order for this system to work successfully, it is necessary to invest in a new type of infrastructure (Wi-Fi network, available high-speed connection), to formulate a special investment policy, to control social inequality and to support broad public debate

Having considered the development stages of the Smart city concept, it can be argued that executives and suppliers of cities recognize that there should be a clearer and quicker path to wider implementation of proven technologies and solutions. We need to understand how to set the right business models and deployment strategies to ensure this expansion. At the same time urban strategy increasingly emphasizes sustainability and climate adaptation and focuses on the development of smart city that is relevant to people and their everyday lives. According to Navigant Research, global intellectual property revenue is expected to increase from $\$ 36.8$ billion in 2016 to $\$ 88.7$ billion by 2025. Consequently, the concept of a smart city is not only implemented within the framework of point projects, but also included in strategic plans for the development of large cities. Digital innovations become road maps to increase human capital and technological breakthroughs throughout the city.

\subsection{The empirical part}

\subsubsection{Results and discussion}

In our opinion, the road map for the development of a "smart city" for Ukraine has the following way of implementing the concept.

First, cities should study their society. Success is impossible without purpose, therefore it is necessary to study the needs of citizens and business, their interests, unique features, way of thinking, level of education, age structure, etc., in order to understand why the population needs a "smart city", which they want to see and what it must change in their environment.

Secondly, when it is determined "why", it is necessary to work out a strategy "how" to implement the concept. Namely, how will the initiatives of the "smart city" be distributed, what are the functions and objectives of such a policy? The implementation of such a strategy requires a "smart government".

Thirdly, the benefits of a "smart city" are aimed, first of all, at the population, on improving its living conditions. Therefore, the idea should be supported by citizens. They 
should be interested in its development, implementation and continuous work on their involvement in the process.

We propose a mechanism to identify the needs of society by the example of the city of Odessa (Ukraine) using the priori ranking method (Bashynska 2015, Tanashchuk et al. 2018). Advantage of the method is in its simplicity and transparency. In our case, a white-held survey of 990 people, 710 people were interviewed online and 280 inperson. Women $-60 \%$, age - from 10 to 75 years. All data was immediately transferred to MS Excel to speed up the data processing process (the online survey was conducted using a tablet, online using Google Forms). The way is similar with Harish Kumar et al. (2018)

The survey took place in two stages: first, the main signs for the smart grid for the population were identified ( 6 main characteristics from Table 2): 1) Smart environment; 2) Smart living; 3) Smart people; 4) Smart economy; 5) Smart mobility; 6) Smart governance.

The research found that for the inhabitants of Odessa the main factors (those that need to be developed in the first) are three: 2) Smart living, 5) Smart governance and 6) Smart mobility. Thus, in the second stage, 15 factors were ranked (Table 5):

1. 2.1) Cultural facilities

2. 2.2) Health conditions

3. 2.3) Individual safety

4. 2.4) Housing quality

5. 2.5) Education facilities

6. 2.6) Touristic attractivity

7. 2.7) Social cohesion

8. 6.1) Participation in decision-making

9. 6.2) Public and social services
10. 6.3) Transparent governance

11. 6.4) Political strategies \& perspectives

12. 5.1) Local accessibility

13. 5.2) (Inter-)national accessibility

14. 5.3) Availability of ICT-infrastructure

15. 5.4) Sustainable, innovative and safe transport systems

Next, we use the processing algorithm (Bashynska 2016) and determine the coefficient of significance of each factor, established in general for the group of experts by the formula:

$$
K_{j}=\frac{m \times n-S_{j}}{0.5 \times m \times n \times(n-1)} .
$$

Determine the normative coefficient of significance $S_{\mathrm{f}}$, which is defined as the magnitude of the inverse number of ranked factors:

$$
S_{f}=\frac{1}{n} .
$$

Thus, in our case, the factors for which the value of the coefficient of significance is equal to or greater than the normative coefficient (0.0667) will be considered significant. Summarize results in a Table 6.

Then using MS Excel check whether there are any related (equally) evaluations in the experts' statements (they should not be, under the condition of using the algorithm). Calculate the coefficient of concordance:

$$
\begin{gathered}
W=\frac{12 \times \sum\left(S_{j}-S_{a v}\right)^{2}}{m^{2} \times\left(n^{3}-n\right)} ; \\
W=\frac{12 \times 230408040}{980100 \times(3375-15)}=0.839 .
\end{gathered}
$$

\begin{tabular}{|c|c|c|c|c|c|c|c|c|}
\hline \multirow{2}{*}{$\begin{array}{c}\text { Expert } \\
\text { number }(\mathrm{m})\end{array}$} & \multicolumn{7}{|c|}{ Factor number (n) } & \multirow{2}{*}{$\mathrm{Si}$} \\
\hline & 1 & 2 & 3 & 4 & 5 & $\ldots$ & 15 & \\
\hline 1 & 15 & 5 & 4 & 6 & 10 & $\ldots$ & 2 & 120 \\
\hline 2 & 15 & 6 & 5 & 4 & 8 & $\ldots$ & 1 & 120 \\
\hline 3 & 14 & 6 & 9 & 10 & 8 & $\ldots$ & 2 & 120 \\
\hline 4 & 13 & 5 & 4 & 10 & 9 & $\ldots$ & 3 & 120 \\
\hline 5 & 14 & 5 & 4 & 6 & 8 & $\ldots$ & 2 & 120 \\
\hline 6 & 13 & 9 & 4 & 15 & 6 & $\ldots$ & 3 & 120 \\
\hline 7 & 11 & 6 & 5 & 4 & 8 & $\ldots$ & 2 & 120 \\
\hline 8 & 15 & 5 & 7 & 8 & 9 & $\ldots$ & 3 & 120 \\
\hline 9 & 15 & 7 & 5 & 11 & 10 & $\ldots$ & 1 & 120 \\
\hline 10 & 7 & 9 & 4 & 6 & 10 & $\ldots$ & 2 & 120 \\
\hline 11 & 11 & 6 & 4 & 5 & 8 & $\ldots$ & 2 & 120 \\
\hline 12 & 11 & 5 & 4 & 6 & 8 & $\ldots$ & 3 & 120 \\
\hline 13 & 15 & 6 & 5 & 4 & 9 & $\ldots$ & 3 & 120 \\
\hline$\ldots$ & $\ldots$ & $\ldots$ & $\ldots$ & $\ldots$ & $\ldots$ & $\ldots$ & $\ldots$ & 120 \\
\hline 990 & 8 & 12 & 11 & 13 & 14 & $\ldots$ & 2 & 120 \\
\hline
\end{tabular}

Table 5. Matrix of expert assessments (fragment) (source: authors 2018) 


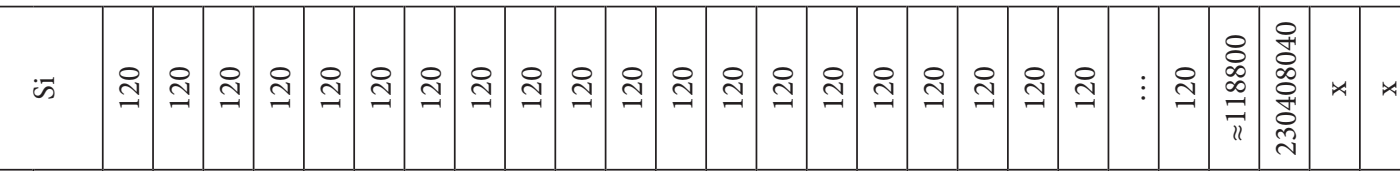

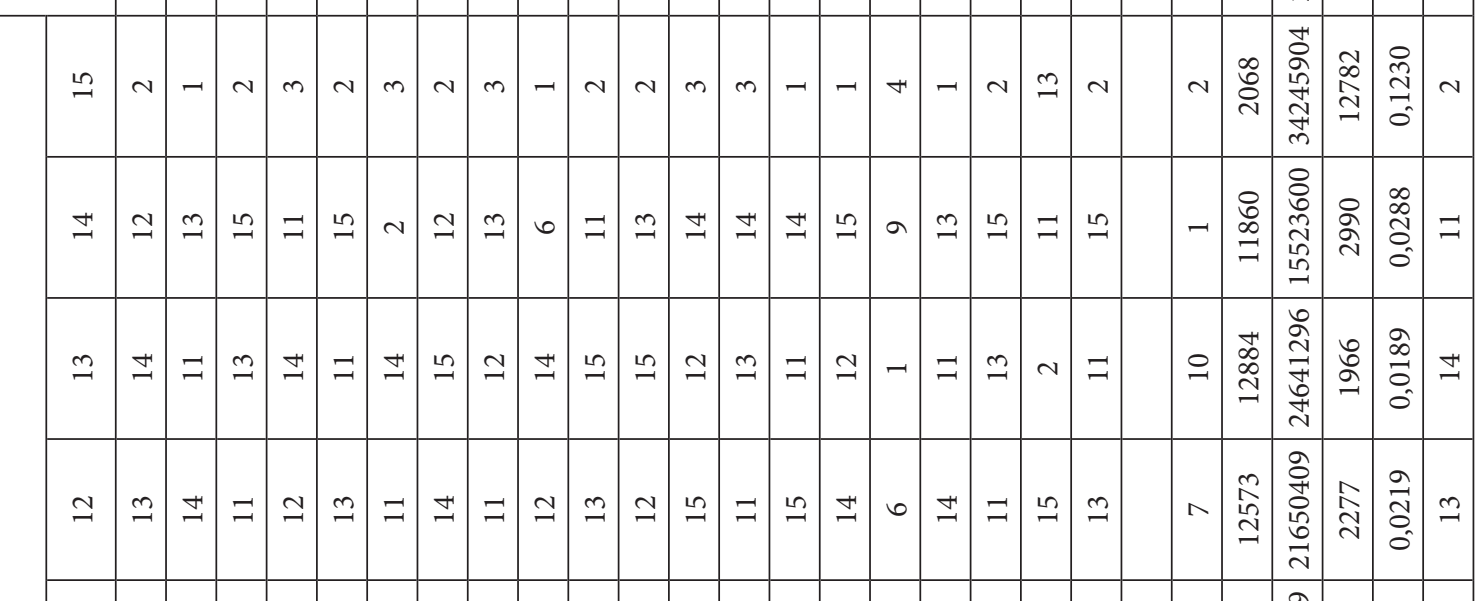

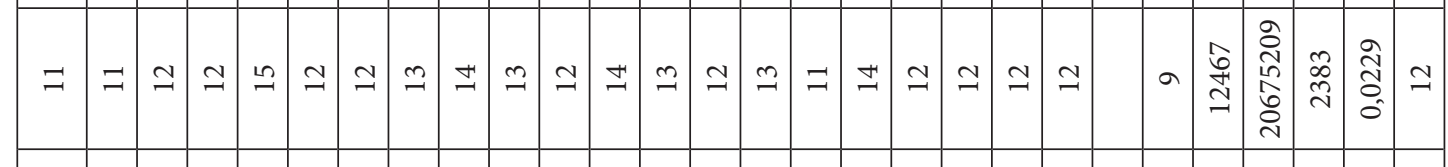

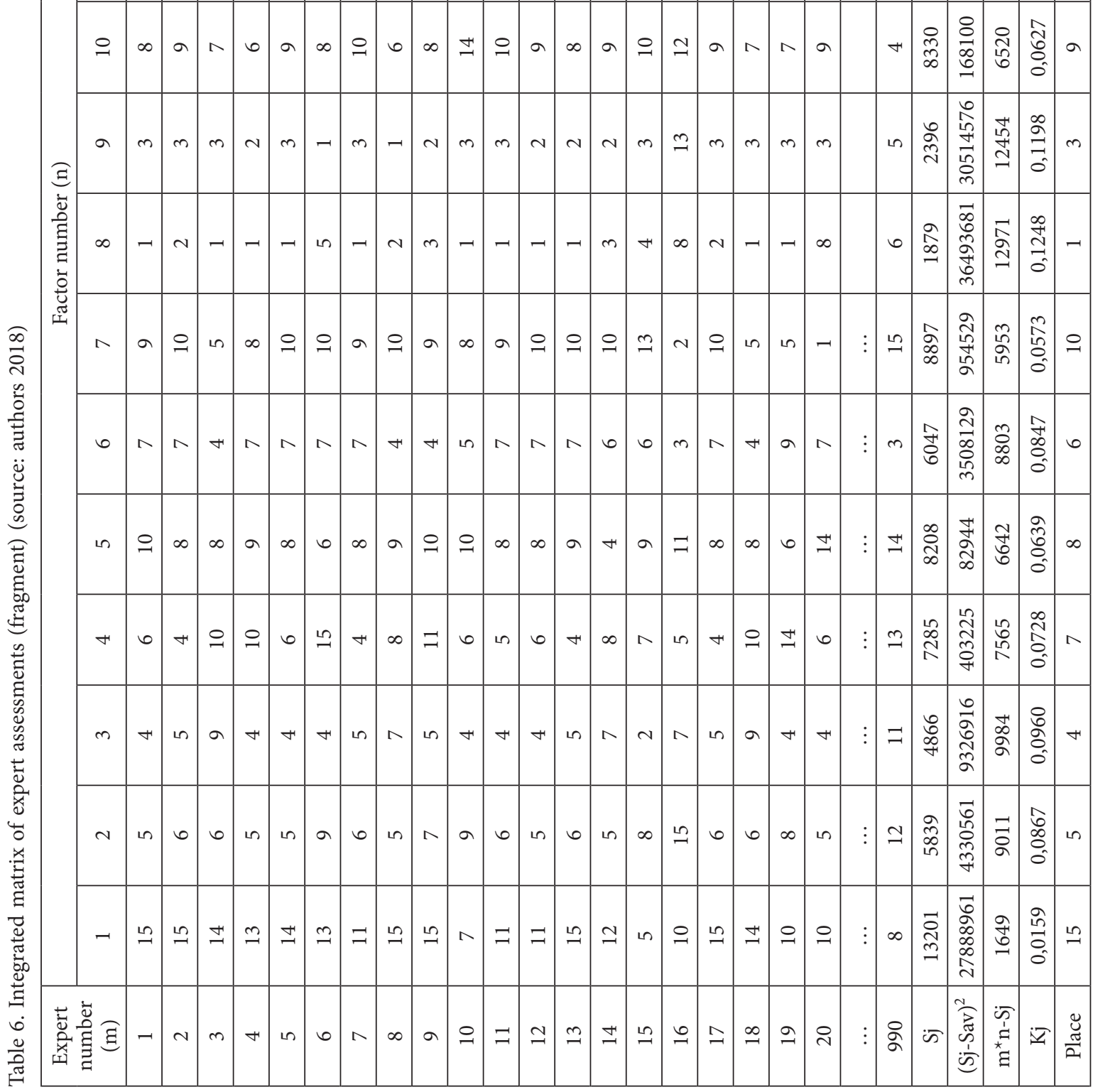


With a coefficient equal to zero, there is no consistency of opinion; with a coefficient equal to one, - the highest level of consistency. So it is checked whether the hypothesis about agreement between experts is accepted and whether it is possible to trust the results of the questionnaire of the expert group.

In our case, the coefficient is quite high, so we can accept the results.

Analysing Table 6, we can draw the following conclusions: residents of the city of Odessa find the following factors the most important for the beginning the smartization (presented in descending order): Participation in decisionmaking, Sustainable, innovative and safe transport systems, Public and social services, Individual safety, Health conditions and Touristic attractivity. Accordingly, the city's leadership should focus on these characteristics, what will allow the government to enlist the support of citizens.

It is worth noting once again that such a procedure should be carried out in every city, because for example, Odessa consider the attraction of tourists an important factor that will not be typical of other, non-recreational cities.

Thus, the hypothesis was confirmed: the map of a city's smartization is unique, but is based on unified defined criteria. In order to develop it, it is first needed to conduct a survey of city residents (by the proposed method), which will firstly secure their support and the process of smartization will go faster, and secondly, it will reveal unique characteristics of the city.

\section{Conclusions}

The growing interest in cities' smartization is connected, first, with the needs of the inhabitants, and secondly, with the development of technologies that open up new opportunities and are applicable in all spheres of life. And for different cities, both the needs of residents and the technologies available to them differ, accordingly, there is can be no single algorithm for cities' smartization. Moreover, the basis and prerequisites also vary among the cities themselves. That is why it is necessary to pay special attention to the preliminary analysis in the city's road map. Moreover, technologies open up new opportunities and sometimes people want to apply everything at once.

However, before starting to work in the three identified directions above, it's important to understand what constitutes the urban community. What is it in the present, what is its geographical boundaries, how it interacts with the community. The work is carried out on the presented algorithm, will allow to study the processes of society, determine the needs of the population and formulate the goals and means for their achievement.

The results of approbation are more valid in Ukrainian culture, as well as in the characteristics and tendencies of
Ukrainian cities. However, due to the fact that at the first stage we identified the characteristics of a smart city based on world experience, the first stage of the empirical research can be used for other cities and countries. The results of this stage by themselves suggest that for the second stage, the residents will be selected characteristics reflecting national specialties.

As part of further research, we consider the promising direction in developing technologies for cities, namely, their synergetic effect. So one technology is cheaper, but the second one allows to solve at once $2-3$ problems of the city, and the third, for example, is absolutely safe. It is the development of an algorithm for selecting such technologies or a technique for calculating their applicability and synergetic effect, which will be an important step in the search for a universal algorithm for smartization, as far as possible.

\section{Acknowledgements}

The authors are thankful for the unconditional support received from DEcon, prof. Filyppova Svitlana.

The research was supported by the Ministry of Education and Science of Ukraine (0017U003804).

\section{Author contributions}

The authors contributed equally.

\section{Disclosure statement}

The authors do not have any conflict of interest.

\section{References}

Achmad KA, Nugroho LE, Djunaedi A, Widyawan W (2018) Smart City readiness based on smart city council's readiness. International Journal of Electrical and Computer Engineering (IJECE) 8 (1): 271-279. https://doi.org/10.11591/ijece.v8i1

Alizadeh T (2018) Crowdsourced Smart Cities versus Corporate Smart Cities. In: The 4th PlanoCosmo International Conference IOP: Earth and Environmental Science 158: 012046 https://doi.org/10.1088/1755-1315/158/1/012046

Almeida VAF, Doneda D, Moreira da Costa E (2018) Humane Smart Cities: the need for governance. IEEE Internet Computing 22 (2): 91-95. https://doi.org/10.1109/MIC. 2018.022021671

Arcadis and the Center for Academic and Business Studies. 2016 Global Sustainable Cities Index: Putting people at the heart of city sustainability (2016) https://www.arcadis.com/en/ united-states/our-perspectives/2016/2016-global-sustainablecities-indexputting-people-at-the-heart-of-city-sustainability/

Attour A, Burger-Helmchen T (2015) Guest editorial. Journal of Strategy and Management 8 (3). https://doi.org/10.1108/ JSMA-06-2015-0046

Bardell A (2018) Living in a Sustainable Smart City. ITNOW 60 (1): 52-55. https://doi.org/10.1093/itnow/bwy024 
Bashynska I (2015) Using the method of expert evaluation in economic calculations. Actual Problems of Economics 7 (169): 408-412.

Bashynska I (2016) Using SMM by industrial enterprises. Actual Problems of Economics 12 (186): 360-369.

Betis G, Cassandras Ch G, Nucci C A (2018) Smart Cities. Proceedings of the IEEE 106 (4). https://doi.org/10.1109/ JPROC.2018.2807784

Bondarev D (2016) I will go to live in Songdo: how to create a utopia from the swamp for 35 billion dollars. Theory\&Practice http://theoryandpractice.ru/posts/13795-songdo

Bradbeer R, Tsang KF (2018) Hong Kong chapter organizes successful smart-city workshop [Society News]. IEEE Consumer Electronics Magazine 7 (2): 11-12. https://doi.org/10.1109/ MCE.2017.2776445

Building a smarter planet, city by city: keynote address at the Smarter Cities Forum, Shanghai (2010) http://www.ibm.com/ smarterplanet/us/en/smarter_cities/article/shanghai_keynote. html

Chaudhary R, Jindal A, Aujla GS, Kumar N, Das AK, Saxena N (2018) LSCSH: Lattice-Based Secure Cryptosystem for Smart Healthcare in Smart Cities Environment. IEEE Communications Magazine 56 (4): 24-32. https://doi.org/10.1109/ MCOM.2018.1700787

Chronicle of events from around the world. Songdo: the city of the future, which already exists (2017) http://hronika.info/ fotoreportazhi/170494-songdo-gorod-buduschego-kotoryyuzhe-suschestvuet-foto.html

Cifaldi G, Serban I (2018) Between a Smart City and Smart Society. In: Intelligent Human Systems Integration (722): 714-719. https://doi.org/10.1007/978-3-319-73888-8_110

Cities Economy General Urban Governance IESE Cities in Motion Index (2017) http://blog.iese.edu/cities-challenges-andmanagement/2017/05/25/164

City Prosperity Initiative (2017) UN-Habitat-2017 https:// unhabitat.org/urban-initiatives/initiatives-programmes/cityprosperity-initiative

Cook DJ, Duncan G, Sprint G, Fritz RL (2018) Using Smart City technology to make healthcare smarter. Proceedings of the IEEE 106 (4): 708-722. https://doi.org/10.1109/ JPROC.2017.2787688

Dias FCA, Cacho NA (2018) A platform for measuring e-participation in Smart Cities: a case study with Brazilian capitals. IEEE Latin America Transactions 16 (2): 542-548. https://doi. org/10.1109/TLA.2018.8327411

Dyskina A (2017) System technologies as an element of smart innovation in the context of the concept of smart grid. Economic Journal of the Odessa Polytechnic University 2 (2): 70-76.

Ernst L, De Graaf R, Peek G-J, Loorbach D (2015) Sustainable urban transformation and sustainability transitions; conceptual framework and case study. Journal of Cleaner Production 112. https://doi.org/10.1016/j.jclepro.2015.10.136

Ericsson (2016) City index https://www.ericsson.com/en/trendsand-insights/networked-society-insights/city-index

European Parliament (2014) Mapping Smart Cities in the EU http://www.europarl.europa.eu/RegData/etudes/etudes/ join/2014/507480/IPOLITRE_ET(2014)507480_EN.pdf
Finger M, Razaghi M (2016) Conceptualizing "Smart Cities". Informatik Spektrum 40 (1). https://doi.org/10.1007/s00287016-1002-5

Gascó M, Rosenthal-Sabroux C, Negre E (2016) Introduction to the Smart Cities and Smart City government minitrack. In: 2016 49th Hawaii International Conference on System Sciences (HICSS). http://doi.ieeecomputersociety.org/10.1109/ HICSS.2015.278

Geoffron P (2017) Smart Cities and Smart Mobilities. In: The Automobile Revolution. Springer. https://doi.org/10.1007/9783-319-45838-0_6

Goldenberg S (2016) Masdar's zero-carbon dream could become world's first green ghost town. The Guardian https://www. theguardian.com/environment/2016/feb/16/masdars-zerocarbon-dream-could-become-worlds-first-green-ghost-town

Gómez-Expósito A, Arcos-Vargas A, Maza-Ortega JM, RosendoMacías JA, Alvarez-Cordero G, Carillo-Aparicio S, GonzálezLara J, Morales-Wagner D, González-García T (2018) Cityfriendly smart network technologies and infrastructures: the Spanish experience. Proceedings of the IEEE 106 (4): 626-660. https://doi.org/10.1109/JPROC.2018.2793461

Hammoudeh M, Arioua M (2018) Sensors and actuators in Smart Cities. Journal of Sensor and Actuator Networks 7 (1): 8. https://doi.org/10.3390/jsan7010008

Hou W, Ning Z, Guo L (2018) Green survivable collaborative edge computing in smart cities. IEEE Transactions on Industrial Informatics 14 (4): 1594-1605. https://doi.org/10.1109/ TII.2018.2797922

ISO 37120:2018 Sustainable cities and communities - Indicators for city services and quality of life https://www.iso.org/obp/ ui/\#iso:std:iso:37120:ed-2:v1:en

Kai C, Li H, Xu L, Li Y, Jiang T (2018) Energy-efficient deviceto-device communications for Green Smart Cities. IEEE Transactions on Industrial Informatics 14 (4): 1542-1551. https://doi.org/10.1109/TII.2017.2789304

Kumar H, Singh MK, Gupta MP, Madan J (2018) Moving towards smart cities: solutions that lead to the Smart City transformation framework. Technological Forecasting and Social Change. https://doi.org/10.1016/j.techfore.2018.04.024

Linsday G (2010) Building a Smarter Favela: IBM Signs Up Rio. Fast Company https://www.fastcompany.com/1712443/ building-smarter-favela-ibm-signs-rio

Lindskog H (1997) Smart communities guidebook: how California's communities can thrive in the digital age. San Diego: State University of San Diego https://www.researchgate.net/ publication/228371789_Smart_communities_initiatives

Lu W, Gong Y, Liu X, Wu J, Peng H (2018) Collaborative energy and information transfer in green wireless sensor networks for Smart Cities. IEEE Transactions on Industrial Informatics 14 (4): 1585-1593. https://doi.org/10.1109/TII.2017.2777846

Mason P (2015) We can't allow the tech giants to rule smart cities. The Guardian https://www.theguardian.com/commentisfree/2015/oct/25/we-cant-allow-the-tech-giants-torule-smart-cities

Ministry of Infrastructure of Ukraine (2014) https://mtu.gov.ua/ files/202014-47-.pdf

Mutiara D, Yuniarti S, Pratama B (2018) Smart governance for smart city. IOP Conference Series: Earth and 
Environmental Science 126 (012073) http://iopscience.iop. org/article/10.1088/1755-1315/126/1/012073/meta

Navigant Research (2016) Smart technologies and infrastructure for energy, water, mobility, buildings, and government: global market analysis and forecasts https: //www.navigantresearch. com/research/smart-cities

Nicolaï I, Le Boennec R (2018) Smart mobility providing smart cities. In: Towards a Sustainable Economy: Paradoxes and Trends in Energy and Transportation. Springer. https://doi. org/10.1007/978.3.319.79060.2

Pan W, Cheng G (2018) QoE assessment of encrypted YouTube adaptive streaming for energy saving in Smart Cities. IEEE Access 6: 25142-25156. https://doi.org/10.1109/ACCESS.2018.2811416

Pinheiro Junior L, Cavalheiro LD (2017) Smart Cities: a research agenda of the Brazilian Smart Cities. In: 14th CONTECSI International Conference on Information Systems and Technology Management. Sao Paulo, SP (Brazil) https://doi. org/10.5748/9788599693131-14CONTECSI/PS-4646

Portmann E, Finger M, Engesser H (2016) Smart Cities. Informatik Spektrum 40 (1). https://doi.org/10.1007/s00287-0161000-7

Razaghi M, Finger M (2018) Smart Governance for Smart Cities. Proceedings of the IEEE 106 (4): 680-689. https://doi. org/10.1109/JPROC.2018.2807784

Shahidehpour M, Li Z, Ganji M (2018) Smart Cities for a sustainable urbanization: illuminating the need for establishing smart urban infrastructures. IEEE Electrification Magazine 6 (2): 16-33. https://doi.org/10.1109/MELE.2018.2816840

Shapiro A (2015) South Korean city designed for the future takes on a life of its own. NPR http://www.npr.org/sections/ parallels/2015/10/01/444749534/a-south-korean-city-designed-for-the-future-takes-on-a-life-of-its-own

Smart city of the future - Songdo (South Korea) (2016) http:// www.biowatt.com.ua/trends/umnyj-gorod-budushhegosongdo-yuzhnaya koreya

Solic P, Patrono L, Perkovic T, Almeida A (2018) Smart Cities. Journal of communications software and systems 14 (1): 1-3. https://doi.org/10.24138/jcomss.v14i1.546

Tanashchuk K, Kovtunenko K, Kovtunenko Yu (2018) Theoretical and Methodical Principles of Capital Structure Management in the Innovation Activity of Telecommunication Operators. Journal of Automation and Information Sciences 50 (3): 71 84. http://10.1615/JAutomatInfScien.v50.i3.60

Technologies for smart cities (2017) Report: St. Petersburg: Foundation "Center for Strategic Research" North-West, 110 pp. http://www.csr-nw.ru/files/publications/doklad_tehnologii_dlya_umnyh_gorodov.pdf

The Arab world (2016) Ecologically clean city of the future Masdar in the UAE http://arabmir.net/node/4209

The concept of Kyiv Smart City 2020 (2017) https://www.kyivsmartcity.com/concept

Top 10 Smartest Cities in The World (2017) https://www.wirelessdesignmag.com/blog/2017/11/top-10-smartest-cities-world
Top 5 smartest Smart Cities in the world (2017) http://www. cbronline.com/news/internetof-things/smart-cities/top5-smartest-smart cities

Venkatesh J, Aksanli B, Chan Ch S, Akyurek AS, Simunic Rosing T (2018) Modular and personalized Smart Health Application Design in a Smart City Environment. IEEE Internet of Things Journal 5 (2): 614-623. https://doi.org/10.1109/ JIOT.2017.2712558

Vienna University of Technology (2007). Smart cities: ranking of European medium-sized cities http://www.smart-cities.eu/ download/smart_cities_final_report.pdf

Wang T, Bhuiyan ZA, Wang G, Rahman A, Wu J, Cao J (2018) Big Data reduction for a Smart City's critical infrastructural health monitoring. IEEE Communications Magazine 56 (3): 128-133. https://doi.org/10.1109/MCE.2017.2717198

World Smart city (2016) The winners of the 2016 World Smart City Awards http://www.smartcityexpo.com/ru/cfa-finalists

Woyke E (2018) Asmarter smart city. Technology review 121 (2): 60-65.

Zambonelli F, Salim F, Loke SW, De Meuter W, Kanhere S (2018) Algorithmic governance in Smart Cities: the conundrum and the potential of pervasive computing solutions. IEEE Technology and Society Magazine 37 (2): 80-87. https://doi. org/10.1109/MTS.2018.2826080

Zhang Y, Jiang C, Wang J, Han Z, Yuan J, Cao J (2018) Green WiFi implementation and management in dense autonomous environments for Smart Cities. IEEE Transactions on Industrial Informatics 14 (4): 1552-1563. https://doi.org/10.1109/ TII.2017.2785820

Zhou L, Wu D, Chen J, Dong Z (2018) Greening the Smart Cities: energy-efficient massive content delivery via D2D communications. IEEE Transactions on Industrial Informatics 14 (4): 1626-1634. https://doi.org/10.1109/TII.2017.2784100

Zinchenko O (2018) Approaches to strategic planning of smearing in some of the world's cities http://www.researchclub. com.ua/journal/405

\section{APPENDIX}

\section{Notations}

Variables and functions

$K j$ - coefficient of significance of each factor;

$\mathrm{Si}$ - sum of ratings on rows;

$S j$ - sum of ratings by columns;

$S f$ - the normative coefficient of significance;

Sav - average columns amount;

$m$ - in total judges;

$n$ - in total objects;

$W$ - coefficient of concordance. 